\title{
Online Instructions: Problems and Potentials for the Teaching of English in Indonesia
}

Patrisius Istiarto Djiwandono Universitas Widya Karya, Malang

\begin{abstract}
This paper reports the results of a survey of a one-semester online course for students majoring in Economics, Secretarial, Computer Technology, and Language Education. The teacher created online materials of reading strategies along with the assignment on www.blackboard. com, and the students were instructed to access the materials, learn them independently, and do some self-evaluated reading assignments. Questonnaires were then distributed to see what obstacles had hampered their efforts in learning from online materials, as well as what advantages they gained from the new instructional approach. The qualitative and quantiative data culled from the questionnaires revealed potentials as well as some latent problems in carrying out an online teaching. The general profile that emerged was learners who were enthusiastic about learning through Internet and felt that the new approach had familiarized them with the future's technological tools, but who were mostly hampered by the lack of fund and facilities. These are discussed with special reference to the use of advanced computer technology in the teaching of English in Indonesia.
\end{abstract}

Keywords: online course, information and communication technology, Internet

The rapid advances in the Information and Communication Technology have been providing vast opportunities for almost every area of life. The Internet and World Wide Web, for instance, with their ubiquitous and egalitarian nature, have opened up more possibilities for innovative approaches to instructional practices that so far rely almost exclusively on traditional, 
face-to-face classroom sessions. These cyberspace technological tools have made it possible for the education system to devise learning activities that go beyond the confine of classroom walls and limited classroom hours. LeLoup and Ponterio (1995:36) point out aptly that:

[The Internet and World Wide Web] are no longer the tools of the future; they are the tools of today. Students need to develop competencies for participation in an information society, for the job skills of a global economy, for lifelong learning, and for personal pleasure. Exposure to, familiarity with, and regular use of FL information on the Internet is paramount to students' and teachers' professional development

Despite the increasing popularity of Internet as an alternative means for delivering instructions, many teachers as well as students seem to remain largely ignorant and uninformed of this amazing development. In the absence of extensive studies that highlight this issue, especially in the context of teaching English in Indonesia, it is difficult to pinpoint any specific causes of this. Whether the information and computer technology (ICT) has indeed some potentials to offer to the teaching and learning English is an open question that is yet to be answered. This paper reports a preliminary investigation into the issues of online English courses for learners of various majors. It specifically probes into the values of such approach for the learners as well as some possible shortcomings that further attempts might want to circumvent in the future.

\section{CHARACTERISTICS OF CONVENTIONAL LEARNING}

Online courses are advanced as alternatives for improving the efficiency of conventional classioom instructions. The latter unguestionably requires a physical place at which learners and teachers must gather in order for the lesson to be conducted properly. This of course entails problems of time and space along with the cost of travel (Tiffin and Rajasingham, 1995). Added to this is the heavy teaching load that many times makes it hardly possible for the lecturer to finish the whole course in one semester.
The online course was advanced to the students because of their asynchronous nature, a feature which enables participants to work on the materials at their own convenience times and practically from unspecified locations. Moreover, the online approach may open up opportunities for the participants to access other learning resources, such as other students, outside experts (including the lecturer), online libraries, or databases, all of which can be accessed from one computer terminal. This capacity makes the approach ideally suited for leamers who may be physically or geographically separated (Mayadas, cited in Alexander, 1999). Added to this is the fact that it heiped the researcher (who also served as the lecturer of the leamers involved in the present study) deliver the course contents more efficiently, since while the main contents still needed to be discussed in classroom sessions, some other contents could be put online for the learners to study on their own and practise independently. All in all, with these features the online approach may give impetus to independent learning.

\section{UNDERLYING PRINCIPLES}

The attempt to introduce instructions through the use of Information and Telecommunication Technology (ICT) is couched on the principle of Constructivism. Constructivism postulates that learning is basically student-centred, and thus emerges from the student's initiatives in constructing his or her knowledge by exploring the world and seeking insights through discovery learning. Rather than wait for an external agent (i.e. teacher) to transfer the knowledge to them, learners actively seek for information and interpret it using their intellectual capacity (Grau and Bartasis, 2000). As they go about this task, they also make use of social relationships with other learners to enhance their knowledge. It is at this junction that the principle intersects with Vygotsky's theory of zone of proximal develop. ment. His well-known theory simply posits that humans learn better when they interact with others, who may be more knowledgeable or more experienced (Vygotsky, 1978). Thus, ICT comes right on time to buttress this constant self-initiated search for knowledge and the accompanying social relations that enhance the learning outcomes. Through the use of Internet learners are enabled to broaden their knowledge and enhance the quality of 
human interactions (by e-mail systems, electronic conferencing, newsgroups, and numerous other cyberspace facilities) which in turn promotes better learning outcomes.

Before a more definite policy on the inclusion of ICT technology in the educational sphere can be considered further, it is important that the characteristics of learners be identified. The ICT-based education is essentially a distance learning, and in this respect Galusha (1997:1) argues that since "distance learning is student-centered learning, . . knowing the characteristics and demographics of the distance learners helps us understand the potential barriers to learning". The present study is a preliminary attempt to chart the demographic factors of the learners.

More specifically, the study was a small-scale exploratory research that aimed at achieving the following objectives: (1) to see how the learners responded affectively as well as cognitively to the online instructions; (2) to identify the strength and the weaknesses of the online approach.

To achieve the research objectives, the researcher also used a qualitative approach in the survey by noting all of the occurrences that may contain hints about how learners reacted to the approach. This included observations of how many of them used the cyberspace technology to contact the lecturer. In addition, the researcher constructed a set of questions in a questionnaire that were given to the participants near the end of the semester. The instrument contains questions which elicited the learners' responses that are relevant to the objectives of the study

\section{THE ONLINE COURSE FOR ALL MAJORS: READING STRATEGIES}

As many as 94 learners from five academic majors were involved in the project. They were 37 students of Economics, 13 learners of Computer and Information Technology, 11 of Secretarial, and 33 learners of English Education. To obtain comparable data across the majors, the researcher exposed the learners to a reading strategy course that was put online. The course materials was a written explanation about how to utilize skimming and scanning in a hierarchical fashion in order to read an English passage efficiently (see Djiwandono, forthcoming). All learners were instructed to access the course URL, that is www.blackboard.com/courses/READ1 to see the course materials and the instruction in the assignments. Upon reading and understanding the explanation in the course material, they were led to the assignments, which instructed them to obtain an authentic reading text from the lecturer and applied what they had read from the course material to answer the questions posed on the text. Besides, they were told to note the time they needed to complete this assignment, and report the results to their lecturer. The deadline for the reports was the end of May 2000 .

In addition to the uniform online course described above, two of the majors-Economics, and Secretarial-had their own assignments.

The former was assigned to access the Course Document of another online course at http:/blackboard.com/courses/ECOR1. The task was to read one Indonesian article on stock trading and translate it into English. The Course Document on this site provided the translation of some key words of the text, thus assisting the students to do their task.

The secretarial students were to access a course in Business English (www. blackboard.com/courses/BUSENG1), and do two assignments: (1) provide appropriate expressions to some social situations in English-speaking cultures; (2) write a business letter according to the instruction given in the assignment. The topics of the letter were changed each month in the course of one semester. The students could submit their work through email or hand it over to the lecturer, though they were encouraged to do the former. The deadline for the submission of each writing topic was the end of each month.

The online courses were set up with the intention of providing the learners with skills that were not covered by the traditional face-to-face classroom sessions. In this way, the researcher hoped that the students will be spurred to develop their independent learning. It was expected that this mode of instruction would train them to cooperate with their friends, and seek more additional information on their own initiatives by utilizing the tools of modern technology (e-mail, Internet).

Attempts were made to create a conducive situation to independent learning, which is a primary characteristic of online learning. As the courses unfolded, the lecturer deliberately refrained as much as possible from in- 
tervening with the learners' progress in their online work. They were left on their own as much as possible. They could do their assignment whenever they liked, with whatever resources they could get hold of, discuss it with their groups or work on it individually. Only when some of them took the initiatives to contact the lecturer in person or though e-mail would the lecturer gave the necessary help. Even so, most of the time the lecturer would just encourage them to seek the answers through discussions with their peers, or through other available sources.

\section{RESULTS}

Before reporting the details of the results, it is necessary to state that most of the learners shared something in common: most of them $192.55 \%$ of the respondents) did not have their own computers or personal access to the Internet. So they had to borrow the machines from their friends or go to the WarNet (Internet Cafes) and rent the computers to access the online course in www,blackboard.com

\section{The General Impressions on the Online Course}

To attain the first research objective, namely, to see how the learners responded affectively as well as cognitively to the online course, the respondents' answers elicited by the questionnaires were tabulated, generating a summary such as shown in the tables below (the italicized sentences above the table are the questions asked in the questionnaire) ${ }^{1}$ :

\section{Table 1}

\section{"Did you find the online course useful?"}

\section{Opinions}

The online course is very useful

Percentage of answers (\%)

The online course is moderately usefu

The oniine course is not useful at all

No opinion
45.74

6.38

7.45
Table 2

"What is your impression about the new approach using the Internet?"

Opinions

Percentage of answers (\%)

It wastes time and energy

It is more difficult than the classroom lessons

41.48

is not much different from the classroom teaching

It gives more knowledge on computer and Internet

technicalities

\section{The Advantages of Following the Online Course}

To achieve the second objective, namely, to identify the strength and weaknesses of the online course, some relevant answers from the questionnaires are summed up in the table below:

Table 3

"What advantages did you gain from the online course?"

(this question allows for more than one answer)

\section{Advantages}

Percentage of

Getting more skillful in using computers and accessing the Internet answers (\%)

Enjoying variations of instructions

Allowing for more flexible schedule

Becoming more independent

\section{Table 4}

"What obstacles did you find in following the online course?" (this question allows for more than one answer) 
Obstacles

Percentage of answers (\%)

Having to spend more money on renting computers

Having problems following the English instructions on the Internet

29.79

22.34

Slow access to the course site

18.08

Difficulties in allocating time for accessing the course on the Internet

\section{Table 5}

"What were the weaknesses of the online course?" (this question allows for more than one answer)

\section{Weaknesses}

Percentage of answers (\%)

Burdening students with extra expenses for renting computers

friends under the guidance of the lecturer

Encouraging some learners to rely too much on their friends

Difficulties in contacting the lecturer if problems arise
A further interest was in finding how the learners resolved learning problems that may have arisen when reading the online materials or doing the online tasks. Their answers are displayed in the following table:

\section{Table 6}

"How did you solve problems that you encountered when doing the online tasks?"

(this question allows for more than one answer)

\section{Ways to solve the problem}

Asking friends/relatives for help Percentage of answers (\%)

Trying to get in touch with the lecturer Trying to solve the problem independently

Utilizing the Internet to find solutions

71.28

20.21

19.15

5.32

\section{Some Qualitative Results}

Besides the findings on the quantitative data as shown above, the study also captured some qualitative data that were generated by observations of the respondents' behaviors. As apparent from the summary below, the uses of e-mails and other technological devices imply some potentials as well as threats in the teaching-learning modes geared for the future information era.

- Shortly (4 days) after the course plan containing the explanation on how to access the online materials had been distributed, a student (Vivent), using a free-email (Yahoo.com) wrote a message to the lecturer. He asked why the materials on the Lecture Notes cannot be copied into his disk.

- A student (Evonne) showed up bringing a print out of the Lecture Notes (a section on the online course which bears the lecturer's explanation). Georgius utilized his e-mail to ask whether the translation task could be done before the reading task.

- Again, Vivent e-mailed the lecturer, complaining that the reading assignment was too difficult to translate. The lecturer replied by giving encouragement, insisting that he could do it little by little with the help of his peers and dictionaries. The point to be imparted to the students was that the students of online teaching was meant to be independent of the lecturer's guidance.

- Octavianus e-mailed the lecturer to ask several questions, including the meaning of some words. The lecturer refrained from helping with the latter, and just encouraged him to solve the language problems with his own efforts, again emphasizing the independence of the on-line task. 
- Being unable to attend the regular face-to-face classes due to his job, a student from D3 Mitek accessed the online course and submitted the assignment through e-mail. The lecturer quickly corrected the work, and sent it back to the student.

The potential of the ICT technology is clear from the above cases: it resolves the problem of distance and time limitation, enabling students to interact with the lecturer, submit assignments, and get the immediate feedback relatively more quickly. The uses of e-mail communication showed that the students may have had genuine interests in the new approach to the extent that prompted them to utilize the e-mail system.

On the other hand, the ease of downloading online materials onto a disk, or copying them on paper may also discourage other students from accessing the online materials themselves; instead of doing so, they'd rather copy from the disks of their friends who had accessed the materials, or read the printed materials. Again, this indicates that technology-induced ease and practicality may backfire by leading some lazy, cash-strapped students to 'hitchhike' on other more hardworking students. Quite a number of the respondents (37.23\%, see Table 5) confirmed this shortcoming. As many as $3.19 \%$ of them admitted that they never accessed the online materials themselves, and just copied from the print-out of their friends who had accessed the materials.

\section{DISCUSSION}

It is clear from Table 1 above that the online instructions were met with the students' enthusiasm. This is further confirmed by their opinions on the advantages of using the approach (see Table 3 ). Thus, it is evident from the findings that most subjects $(61.7 \%$ ) actually felt that the new approach somehow familiarized them with computer and Internet technicalities. Prior to following the online course, many were probably largely ignorant about the know-how of using computers to access the World Wide Web through the Internet. The online course compelled them to turn their attention to these technologies. Soon after their first attempts, they found that the vast world containing rich sources of knowledge were only a few mouse-clicks away from their hands. That was when they realized the potentials of the Internet as a means of learning.

Added to this is the fact that another significant portion of the respondents $(52.13 \%)$ enjoyed having online sessions as variations besides the regular classroom sessions. A considerable number of them $(24.47 \%)$ enjoyed the flexibility with which they could access the course and work on the assignments. In addition, $19.15 \%$ of them admitted that the new approach had taught them to be more independent in their learning. These are the side effects of the online course that proved to be benevolent for the learners.

The profile just discussed offers a hope that Indonesian leamers may stand poised for the coming information era. The era is mainly characterized by (1) the repositioning of the students to the center of learning, with the teacher as facilitator rather than expert, (2) the use of computers as a medium which reorganize interactions among people and serve to connect with other individuals or outside worlds beyond the classroom (Cole and Griffin, 1987), (3) a vast array of cyberspace facilities such as newsgroups, electronic conferencing, e-mail, and World Wide Web that will augment the interactions between learners and their sources of learning beyond the traditional teaching situations (Kern, 1996). At the present condition where sparks of interest and motivations are emerging it is necessary that the educators and educational policy-makers make sustained efforts to step up the ICT-supported learning activities.

\section{Problems with Facilities, Cost, and Basic Skills}

As the ramifications of online instructions grow, educators begin to see some prohibitive obstacles that so far have rendered the new approach marginally successful. The structure of distance learning undoubtedly gives adults the greatest possible control over the time, place and pace of education; however, it is not without problems. Galusha (1997) argues that the problems fall into several distinct categories, namely, costs and motivators, feedback and teacher contact, student support and services, alienation and 
isolation, lack of experience, and training. A number of these factors were found evident among the respondents in the present study.

Positive impressions on the online approach have been recorded. Unfortunately, the enthusiasm for learning beyond the confine of classrooms still got hindered by the lack of fund and facilities. Most of the respondents did not have their private computers with Internet connections. Consequently, they still had to rent the machines at WarNet (Internet Cafes), which in turn forced them to have some ready amount of money for the rent. One of the weaknesses the respondents complained about was the necessity of providing more money for the rent fee of the computers at the WarNets. Apparently, students with limited allowance would find this burdensome for their financial conditions. Moreover, the unavailability of the necessary equipment at home forced them to rearrange their schedule to provide a special time allotment for going to the WarNets, which in turn limited their flexibility in accessing the online courses. Thus, one formidable barrier in setting up an ICT-based education is the problem of coping with huge costs for installing and maintaining the necessary equipment, plus preparing the qualified human resources.

Foremost, the Internet is expensive. Schools will have to buy expensive hardware, software and subscribe to an ISP. Telephone costs

will have to be budgeted for. The teachers will have to be trained,

which costs a lot of money and valuable time (Graus, 1999:42)

Many of the students ( $43.62 \%$ ), notably those from non-English majors, complained that they were feeling apprehensive about using the Internet because of their poor English. This has actually been predicted by educational scholars. They are of the opinion that despite the main goal of creating "education for all", advanced technologies inevitably create the so-called "digital divide" between the rich and the poor, between those with complete facilities and those with less complete equipment, as well as those with sufficient English mastery and those with inadequate command of English. Wagner (1999) comments on this obvious fact:

diversity is one of the most important features in understanding why narrowly focused, middle-class oriented, and "one size fits all" education programs-especially when complex technology is introduced-have often met with poor results and lots of resources. Indeed, even the current dominance of the English language on the WWW has had, as a consequence, an exclusionary aspect to it.

Graff (1999:42) could not agree more when he states this:

As the information revolution picks up the pace, these differences (in wealth) could deepen, dividing the world into those who have access to knowledge and technology and those who do not.

The lack of facilities is especially acute in Indonesia, where people with telephone lines comprise only $3 \%$ of the entire population, and people who have computers at their homes are only $3.7 \%$ of the population (Pattiradjawane, 2000:22).

Some information that was also elicited but was not shown in the results above concerns the difficulty of understanding and doing the online tasks. In general, many learners $(24.47 \%)$ still found that the lecturer's online explanation was moderately difficult, while $8.51 \%$ of them felt that it was very difficult to understand. As many as $27.66 \%$ of them say that the assignments were difficult, while $9.57 \%$ felt they were extremely difficult. This profile seems to accord with their opinion in Table 5, in which $44.68 \%$ said that the online materials were somehow unsuited for independent learning; they still need a traditional face-to-face classes with their friends and lecturer to cope with the difficulty of the materials. This information may reveal some underlying reasons. First, they may not have made enough attempts to seek other sources of knowledge from the Internet (which may be caused by lack of fund or facilities) or other non-Internet materials; secondly, they could not access the lecturer personally and ask for help; thirdly, they may not have cooperated with their peers in a way that helped them solve their problems.

As Table 4 shows, several respondents $(22.34 \%)$ reported the slow response of the hardware in delivering the online materials. Gale (2000) reports that technology problems are the second most often cited reason for the dropping out rate of online courses. Apparently, the access to the course site on the Internet slows down a little or even gets stuck during the peak 
hours of telecommunication. This gets worse if the students use outdated computers or browsers. So, it is necessary that telecommunication technology be continually enhanced to accommodate the increasingly busier cyber communication in a given population.

\section{The Minimal Use of ICT Technology}

With such barriers, it is just understandable that when confronted with difficulties, the respondents never consulted other sources on the Internet. Rather than search for the solutions by spending more time on the Internet and thus raising the cost and increasing the headaches already posed by their limited English proficiency, most of them (about 90\%) preferred to consult their peers, relatives, or teachers. Internet was virtually never considered as a source for solutions (only $5.32 \%$ of the respondents used it). This characteristic probably makes them not very well-suited to the era of independent learning in the information age, which emphasizes viable skills in computer communication and encourages learners to employ the skills to access the vast globalized network in order to accomplish their academic tasks.

Had the respondents taken some time to explore the potentials of the world wide web, they would have undoubtedly found some websites that would very much help them with vocabulary problems. They could have utilized search engines such as www.altavista.com to find online dictionaries or other relevant sources. They could have got to www.m-w.com which is a very comprehensive online dictionary and thesaurus that cater for $\mathrm{EFL}$ learners; the Economics, Secretarial and Computer Technology students would have greatly benefited from www.facstaff.bucknell.edu/rbeard/ diction $4 . h t m l$, another online dictionary for specific fields. These aids were practically a few clicks away from their hands, yet the unfamiliarity with the Internet technicalities, coupled with poor English proficiency, had barred them from these powerful aids.

\section{CONCLUSION}

The present small-scale survey reveals that in general, Indonesian students still have a long way ahead to get themselves prepared for online instructions. Clearly, there is a lack of basic requirements that include fund and facilities. But, what actually matters more than just enough funding and facilities is the cognitive and affective readiness to adopt more independent learning which is at premium in doing online educational activities. This is supported by Haddad (2000:5) who contends that the so-called digital divide manifests not only in terms of access to the infrastructure of Information and Telecommunication Technology (ICT) but "in the extent and quality of human knowledge and learning". He argues further that it is not a digital, but educational issues which actually underscores the divide; therefore what should be done is "to empower people with appropriate educational, cognitive, and behavioral skills".

Before such a great leap toward ICT-based education can ever be made manifest, teaching practitioners should in the first place ask a very basic question: given the daunting challenges in terms of the appropriate cognitive styles, adequate fund and complete facilities, do EFL teaching and learning need all of the sophisticated niceties the ICT can offer? If students and teachers have so far been able to get by very well without the aids of computers and Internet, will it be worth the money and effort to shift to online instructions? The remark below may be relevant to the above issue:

Technology is only a tool. Educational choices have to be made first in terms of objectives, methodologies, and roles of teachers and students before decisions on the appropriate technologies can be made. The challenge is... to align the learning technologies with these objectives.... Perhaps the most profound shift is from systems of learning and from supervision of learning to facilitation of learning (Haddad, 1999:1).

In the end, the online approach used by the writer in the present study only served to alleviate the lecturer's teaching workload by providing a virtual 'classroom' in a cyberspace for lecture notes and assignments. The approach enabled the lecturer to deliver the full content of the courses without having to be limited by the classroom time and geographical constraints. To 
some extent, it has also raised the learners' awareness of their capacity for independent learning, besides producing a benevolent side-effect of getting them to be more skillful in using Internet technologies. Yet, to some extent, it stopped short of getting the learners to gear their cognitive and affective predisposition to styles that are more conducive to online mode of learning. Learners still resorted to traditional ways for solving their difficulties; instead of finding the solutions by accessing the resourceful Internet sites, creating cyber discussions, or e-mailing their lecturer or their friends, they still preferred face-to-face consultations with their friends and lecturer. By using the information technology they could actually have overcome the barrier of space and time, two constraints which they inevitably had to experience when doing the face-to-face interactions. The point here is not that the latter should be abandoned in favor of the former, but that they should be done in a combination that will lead to a more fruitful result Browsing libraries, reading books, engaging in group discussions, taking tutorial sessions, or consulting the lecturers in person still need to exist to preserve the social nature of the participants; it is when such contact is cut short by time limitation and distance that the participants have to resort to ICT-based approaches and assume the styles of independent learning. In fact, the familiarity with the use of information technological tools is indispensable, such as reflected by the following opinion:

These are no longer the tools of the future; they are the tools of today. Students need to develop competencies for participation in an information society, for the job skills of a global economy, for lifelong learning, and for personal pleasure. Exposure to, familiarity with, and regular use of FL information on the Internet is paramount to students' and teachers' professional development (LeLoup and Ponterio, 1995: 52)

Note:

2 The percentage figures are rounded up; only answers to the questions that are relevant to the present topic are displayed. Some numbers allow for open-ended questions, which explains why some of the figures do not total to $100 \%$.

\section{REFERENCES}

Alexander, J. A. 1999. Collaborative Design, Constructivist Learning, Information Technology Immersion, and Electronic Communities: A Case Study. Interpersonal Computing and Technology: An Electronic Joumal for the $21^{\text {si }} \mathrm{Cen}$ tury, $7: 1-2$.

Cole, M., and Griffin, P. (Eds). 1987. Coniextual Factors in Education. Madison, WI: Wisconsin Center for Education Research.

Gale, C. 2000. An Analysis of Factors That Affect Online Course Completion Rate. www.elsevier.nl/homepage/sag/cal99/output/abs27.htm, 7 May 2000.

Galusha, J. M. 1997. Barriers to Learning in Distance Education. Interpersonal Computing and Technology: An Electronic Journal for the $21^{\text {si }}$ Century 5, (34): $6-14$

Graff, J. 1999. Giving Some of It Back. Newsweek, February 22, pp. 42-46

Grau, I., and J. Bartasis. 2000. Utilizing the World Wide Web to Advance Student Education into the $21^{\text {st }}$ Century. http://inst,cl.uh.edu/inst5931/paper.html, 7 March 2000.

Graus, J. 1999. An Evaluation of the Usefulness of The Internet in the EFL Classroom. Unpublished Master's thesis, University of Nijmegen.

Haddad, W. D. 2000. If Not Digital, Then What. TechKnowlogia March/April 2000

Haddad, W.D. 1999. If Technology is The Solution Where is The Problem? TechKnowlogia, November/December

Kern, R. 1996. Computer-Mediated Communication: Using E-mail Exchanges to Explore Personal Histories in Two Cultures. In Warschauer, M. (Ed.). Telecollaboration in Foreign Language Learning. Honolulu, Hawaii: University of Hawaii Second Language Teaching and Curriculum Center, pp. 105119.

LeLoup, J. W., and R. Ponterio. 1995. Addressing the Need for Electronic Communication in Foreign Language Teaching. In Steinfeldt, R. (Ed.). Educational Technologies. Monograph of the New York State Council of Educational Associations, pp. 39-54

Pattiradjawane, R. 2000. Masa Depan Ada di Jaringan Internet. KOMPAS, 6 May 2000 , pp. 22

Vygotsky, L. S. 1978. Mind in Society: The Development of Higher Psychological Processes. Cambridge: Harvard University Press.

Wagner, D. A. 2000. Literacy, Technological Literacy and the Digital Divide. TechKnowlogia 2:3 


\section{Appendix}

\section{The Questionnaire for the Online Course}

Jurusan Anda:

Selama ini anda telah mengikuti perkuliahan dengan sebagian materi dan tugas yang disajikan lewat situs www.blackboard.com di Internet. Angket ini bertujuan untuk mengetahui hambatan dan prospek yang anda dapatkan selama mengikuti online course ini. Jawablah dengan JUJUR! dengan memberi tanda silang pada abjad. Jawaban anda tidak akan mempengaruhi nilai akhir anda!

1. Apakah pengajaran melalui Internet ini (online course), bermanfaat bagi anda?
a. Ya
b. Cukup bermanfaat
c. Tidak
d. Tidak tahu

2. Bagaimana kesan anda tentang pendekatan baru melalui Internet ini? a. Sama saja dengan pelajaran di kelas

b. Lebih sulit daripada tatap muka di kelas

c. Menghabiskan biaya dan tenaga

d. Alasan lain:

3. Manfaat apa yang anda petik dari online course ini (Jawaban boleh LEBH daripada SATU):

a. Saya jadi lebih banyak tahu tentang komputer dan Internet

b. Saya bisa belajar lebih mandiri

c. Saya menikmati variasi selain tatap muka di kelas

d. Saya bisa lebih luwes mengatur waktu, karena materi bisa diakses kapan saja.

e. Lainnya:
4. Hambatan apa yang umumnya anda hadapi dalam mengikuti pelajaran lewat Internet ini? (Jawaban boleh LEBIH daripada SATU)

a. Kesulitan mendapatkan komputer

b. Harus menambah pengeluaran dana untuk sewa komputer/Internet

c. Waktu akses ke Blackboard.com lama

d. Sulit mengikuti petunjuk Internet yang ditulis dalam Bahasa Inggris

e. Tidak terbiasa memakai komputer

f. Lainnya :

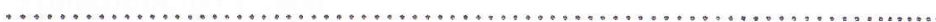

5. Selain manfaat, apakah ada kelemahan dalam pengajaran lewat Internet ini (Jawaban boleh LEBIH daripada SATU):

a. Kerja kelompok membuat ada beberapa orang yang tidak mau kerja, cuma mendompleng hasil teman-temannya.

b. Kalau ada kesulitan, tidak bisa minta penjelasan ke dosen.

c. Membebani mahasiswa dengan dana tambahan untuk sewa komputer.

d. Materi online course tidak sesuai untuk kerja mandiri; perlu tatap muka dgn dosen/rekan di kelas sehingga kesulitan bisa ditanyakan, dibahas, dan diselesaikan bersama.

e. Yang lainnya:

6. Bagaimana menurut anda penjelasan dosen di online course?
a. Mudah
b. Cukup
c. Cukup sulit
d. Sangat sulit
e. Terlalu sedikit
f. Cukup
g. Terlalu banyak

7. Bagaimana menurut anda tingkat kesulitan tugas (assignment) yang diberikan?
a. Mudah
b. Cukup
c. Sulit
d. Sangat sulit

g. Terlalu banyak 
8. Jika anda mengalami kesulitan dalam memahami tugas dan penjelasan itu, bagaimana anda mengatasinya:
a. Minta bantuan teman/saudara.
b. Mengerjakan sendiri sebisanya.
c. Mencari bantuan di Internet.
d. Berusaha menghubungi dosen.
c. Diam saja.
f. Lainnya

9. Apakah anda punya fasilitas komputer dan sambungan Internet di rumah?
a. Ya
b. Tidak

10. Kalau tidak, bagaimana cara anda mengakses online course selama ini?
a. Pinjam teman/saudara
b. Menyewa di Warnet
c. Lainnya :

11. Saran apakah yang dapat anda berikan untuk perkuliahan online course seperti ini?

a. Dihentikan saja, karena membebani mahasiswa

b. Diteruskan dengan beberapa perbaikan

c. Lainnya:

\section{Nomer 12 dan 13 khusus untuk mahasiswi DII Sekretaris!}

12. Selama ini anda telah mengikuti 2 online course: mengenai strategi membaca (READINGl), dan bahasa Inggris niaga (BUSENGI). Manakah dari kedua online course tersebut yang anda anggap lebih sukar?
a. READINGI
b. BUSENGI
c. Dua-duanya sama sukarnya
d. Dua-duanya sama mudahnya

13. Apa yang anda lakukan kalau menghadapi kesulitan dalam memahami/mengerjakan tugas-tugas online tersebut?
a. Meminta bantuan teman
b. Menghubungi dosen
c. Mengerjakan sendiri
d. Lainnya:

\section{TERIMA KASIH}

c:/articles/angket online teach 